\title{
O MERCADO DE TRABALHO
}

Na condição de $4^{\circ}$ anista do Curso de Graduação em Enfermagem, comecei a pensar em questões ligadas ao mercado de trabalho e a situação e inserção do recém formado neste sistema. É fato que até poucos anos atrás a barreira mais temida pelos jovens em busca de um futuro promissor era a passagem pelo vestibular. Após esta etapa, os novos calouros traziam estampados em seus rostos a alegria por terem superado a mais dura das etapas, os novos calouros traziam estampados em seus rostos a alegria por terem superado a mais dura das etapas e de certa forma, por terem mais segurança em suas vidas já que possuindo diploma universitário um bom emprego era esperado.

Hoje essa situação modificou-se e o que assusta não só aos jovens recém formados como também aos profissionais mais experientes é a Seleção de profissionais pelo Departamento de Recursos Humanos (DRH) das instituições empregadoras. Problema este não atual, mas agora mais iminente, os DRH colocam em prática processos cada vez mais seletivos movidos pelo mercado que vem se transformando a cada dia. Essas transformações são frutos de uma era Capitalista ao extremo, que consegue modificar valores, culturas, estilos de vida. Exemplo disso, a Globalização. Num cenário em que há mais candidatos por vagas disponíveis surge um mandamento principal neste sistema: A Competição.

Para garantir um bom emprego nos dias de hoje, já não bastam mais anos de estudo, título de bacharel, cursos noturnos de inglês e conhecimento em computação. Além dessas graduações, as empresas procuram jovens ambiciosos, críticos, criativos, atualizados e flexíveis. Jovens que tenham a capacidade de resolver um problema antes de seus superiores tomarem conhecimento deles. E os profissionais veteranos que não se adaptarem a essa nova ordem, correm o risco de uma possível substituição ou como eles preferem chamar, Reciclagem de pessoal.

Os processos de seleção nas empresas e hospitais já não são os mesmos. Estão em baixa as análises curriculares como metodologia única de seleção. A tendência atual são reuniões em grupos, discussões onde é evidenciado o candidato mais comunicativo, aquele que responde às perguntas mais rapidamente, o mais informado e dinâmico.

Na enfermagem ainda possuímos a vantagem da necessidade de enfermeiros no mercado de trabalho, porém, o jovem estudante que está ingressando, deve

* Aluno do $4^{\circ}$ Ano do Curso de Graduação em Enfermagem da Escola de Enfermagem de Ribeirão Preto da Universidade de São Paulo 
pensar na concorrência desde o $1^{\circ}$ ano e se preparar. Os hospitais e instituições estão a cada dia mais informatizados com equipamentos sofisticados que exigem do enfermeiro conhecimento de outras naturezas de modo a ver holísticamente o ambiente em que está inserido.

Estamos numa época de constante transição sócio-econômica, que tem o poder de mover grandes massas à uma lógica universal. Aqueles que por um motivo qualquer não conseguem acompanhar essa engrenagem, é friamente jogado para fora do sistema e cabe ao fracassado arcar com todas as consequiências.

$\mathrm{O}$ que a empresa procura nos candidatos:

- candidatos precisam mais do que diploma de bacharel, curso de inglês e computação.

As instituições preferem pessoas polivalentes com conhecimentos variados. Os melhores empregos vão para aqueles que têm pós-graduação, ou que já viveram no exterior. Por isso faça tudo para estudar fora.
- Leia jornais. Informações gerais são muito valorizadas hoje.

- Ficar desatualizado hoje é muito fácil e rápido. Portanto não estranhe em ter que retornar à uma instituição de ensino depois de formado. A participação em congressos e demais eventos científicos são excelentes.

- Experiência vale mais do que tempo de serviço. modernos

- Procure emprego em hospitais atualizados e

- A atividade perante o trabalho é mais importante do que o diploma. Hospitais modernos gostam até de um pouco de arrogância do enfermeiro. Pode ser um sinal de que está em condição de liderar.

- Cuide da aparência pessoal.

- É preciso ter ambição. Quem não tem essa capacidade corre o risco de acabar a carreira como profissional não reconhecido depois de muitos anos de trabalho. 